\title{
How well are we engaging the family in family- based treatment for adolescent anorexia nervosa?
}

\author{
Elizabeth K Hughes ${ }^{1,2,3^{*}}$, Claire Burton ${ }^{2}$, Daniel Le Grange ${ }^{1,4}$, Susan M Sawyer ${ }^{1,2,3}$ \\ From 2015 ANZAED Conference: Riding the Waves to Recovery \\ Surfers Paradise, Australia. 21-22 August 2015
}

According to manualised family-based treatment (FBT) for adolescent anorexia nervosa, all family members should attend treatment sessions. However, there is very little research on the degree to which individual family members are involved in clinical practice. We examined the attendance rates of 198 families who participated in FBT at the Royal Children's Hospital Eating Disorders Program. Mothers' attendance was mostly stable over 6 months of FBT, ranging between $91-99 \%$ (mean=95\%). Fathers' attendance declined slowly over time from a high of $83 \%$ down to $61 \%$. (mean $=71 \%)$. Siblings' attendance was $44 \%$ in the first week followed by a rapid decline to a low of $8 \%$ (mean $=20 \%$ ). In total, mothers attended $91 \%$ of all sessions, fathers attended $69 \%$ of sessions, and siblings attended $19 \%$ of sessions. In this presentation, we will discuss the factors that allow our service to achieve relatively high rates of paternal engagement. This includes therapeutic strategies used by clinicians to overcome resistance and service processes that enable and encourage fathers to be involved. We will also discuss factors that may affect sibling attendance and how we can improve engagement with siblings.

\section{Authors' details}

'University of Melbourne, Melbourne, Australia. ${ }^{2}$ Royal Children's Hospital, Melbourne, Australia. ${ }^{3}$ Murdoch Childrens Research Institute, Melbourne, Australia. ${ }^{4}$ University of California San Francisco, San Francisco, CA, USA.

Published: 23 November 2015

doi:10.1186/2050-2974-3-S1-049

Cite this article as: Hughes et al:. How well are we engaging the family in family-based treatment for adolescent anorexia nervosa? Journal of Eating Disorders 2015 3(Suppl 1):O49.

* Correspondence: Libby.Hughes@rch.org.au

'University of Melbourne, Melbourne, Australia

Full list of author information is available at the end of the article

Submit your next manuscript to BioMed Central and take full advantage of:

- Convenient online submission

- Thorough peer review

- No space constraints or color figure charges

- Immediate publication on acceptance

- Inclusion in PubMed, CAS, Scopus and Google Scholar

- Research which is freely available for redistribution 